Review article

DOI: $10.2478 /$ acve-2020-0011

\title{
FOCUS ON COMMON SMALL ANIMAL VECTOR-BORNE DISEASES IN CENTRAL AND SOUTHEASTERN EUROPE
}

\author{
LESCHNIK Michael*
}

Small Animals Clinic, Veterinary University Vienna, Veterinärplatz 1, 1210 Vienna, Austria

(Received 17 January, Accepted 06 April 2020)

\begin{abstract}
Vector-borne diseases are one of the main causes of morbidity and mortality in small animals in Europe. Many of these diseases are well-known among veterinary practitioners and some of them are called emerging diseases as prevalence, temporal and spatial distribution seem to increase in Europe. The number of newly recognized pathogens, transmitted by a variety of arthropod vectors, that are relevant for dogs and cats, is also increasing every year. The prevalence among infected vectors and hosts is a hot topic in veterinary science throughout the entire continent, as well as the development of efficient diagnostic procedures, therapy and prophylactic measures. Companion animal vector-borne diseases comprise a large group of pathogens including viruses, bacteria, protozoa and helminths. These pathogens are mainly transmitted by bloodsucking arthropods (ticks, fleas, mosquitos, sand flies), and more seldom by direct transmission between vertebrate hosts. Vector prevalence and activity is influenced by local climate conditions, host species density, changes in landscape and land use. Human parameters such as poverty and migration affect the use of prophylactic measures against pathogen transmission and infection as well as increasing the zoonotic risk to introducing pathogens by infected humans. Small animal associated factors such as pet trade and pet travel spread infection and certain vectors such as ticks and fleas. All these factors pose several complex and significant challenges for veterinarians in clinical practice to decide on efficient laboratory work-up and constructive diagnostic procedures.
\end{abstract}

Key words: canine babesiosis, diagnostic procedures, dirofilariosis, leishmaniosis, tickborne encephalitis

\section{INTRODUCTION}

Pet ownership in Europe, in 2018, was estimated to include 80 million households with a minimum of one pet. More than 85 million dogs and 104 million cats are mainly living under supervision and are the responsibility of humans that take care of disease prophylaxis and therapy, requesting veterinary recommendations and support [1]. Those prophylactic measures are the top business volume in small animal veterinary

\footnotetext{
*Corresponding author: e-mail: michael.leschnik@vetmeduni.ac.at
} 
medicine and include antiparasitic drugs and vaccines, thus underlining the importance of infectious diseases [2]. In humans, vector-borne diseases (VBDs) represent more than $17 \%$ of all known infectious diseases [3]. In dogs, the infection risk for tick-borne pathogens has been calculated as $54 \%$ per year leading to the assumption, that vectorborne diseases are even more important in pet animals compared to humans [4].

Many global processes are thought to affect vector-borne disease dynamics in men and animals. These factors include land-use and change of vegetation influencing vector population, as well as complex socioeconomics [5]. Current climate changes influence regional vector introduction, vector shift to higher latitudes and altitudes and extended annual periods of vector activities [6]. Human poverty influences the number and species of pet animals like abandoned animals lead to an increased number of stray dogs and cats. These free roaming animals represent a high-risk population for VBDs because of their permanent exposure to vectors and the lack of prophylactic measures [7]. The expenses spent on animal care (general veterinary supply, prophylactic measures such as antiparasitic procedures, vaccination), could drop as financial resources of pet owners decrease. The opportunities to travel and to take pet animals along could have a major influence on the distribution and occurrence of vector-borne diseases [8].

Diagnostic procedures in VBDs are variable and are based on the veterinarian's experience and education, and financial limitations of pet owners. Starting with a comprehensive patient history, including animal origin and possible travel history, prophylactic measures (vaccinations, endo- and ectoparasite control), outdoor access (especially in cats) and other lifestyle and environmental conditions, as well as specific parameters such as age, gender and breed, is necessarily important to bring clinical signs in line with efficient and target oriented diagnostic procedures. Clinical examinations will usually display unspecific acute clinical signs such as fever, shifting lameness and myalgia, lymphadenomegaly and splenomegaly, whereas more chronically progressed diseased patients present with recurrent fever, weight loss, exercise intolerance and pale mucosals. Initial hematological work-up commonly gives results such as hemolytic, regenerative or hypo-regenerative anemia, thrombocytopenia, elevated total protein and proteinuria depending on the phase and time course of the disease [8]. Combining further laboratory work-up efficiently with additional information from the patient's history might help to identify one or more disease-causing pathogens or its resulting organ manifestations, which then should lead to curing or symptom relieving therapy. As some of these infections are considered an emerging zoonosis, identification and treatment of infected animals is an important contribution to a one-health perspective (Table 1).

This review displays efficient common diagnostic procedures in major VBDs in cats and dogs, as well as possible additional information and parameters that could help to choose efficient laboratory work-up to set the right diagnosis (Table 2). The focus is on the situation of five selected pathogens (Babesia canis, Dirofilaria immitis, Dirofilaria repens, Leishmania infantum, and the tick-borne encephalitis virus) in central and 
southeastern Europe, where the re-occurrence and fast spatial dispersion of vectors and these pathogens has been documented in recent years. The number of cases of these selected vector-borne diseases is increasing in Europe, too [9]. Treatment options are not reviewed in this paper and should be gleaned in current scientific reviews and textbooks.

Table 1. Vector-borne pathogens, canine and feline incidence, pathogenicity, and its zoonotic potential in central and southeastern Europe

\begin{tabular}{|c|c|c|c|c|}
\hline Pathogen/group & Vector & $\begin{array}{c}\text { Canine disease } \\
\text { incidence / } \\
\text { pathogenicity }\end{array}$ & $\begin{array}{c}\text { Feline disease } \\
\text { incidence / } \\
\text { pathogenicity }\end{array}$ & $\begin{array}{c}\text { Human disease } \\
\text { incidence / } \\
\text { pathogenicity }\end{array}$ \\
\hline $\begin{array}{l}\text { Dirofilaria immitis / } \\
\text { helminths }\end{array}$ & mosquitos & high / high & low / moderate & low / moderate \\
\hline $\begin{array}{l}\text { Dirofilaria repens / } \\
\text { helminths }\end{array}$ & mosquitos & high/ low & low / low & low/ moderate \\
\hline B. canis / protozoa & $\begin{array}{l}\text { hard tick } \\
\text { Ixodes ricinus }\end{array}$ & high / high & no & no \\
\hline $\begin{array}{l}\text { TBE-virus / } \\
\text { Flavivirus }\end{array}$ & $\begin{array}{l}\text { hard tick } \\
\text { Ixodes ricinus, } \\
\text { Dermacentor } \\
\text { reticulatus }\end{array}$ & low / high & no & moderate / high \\
\hline $\begin{array}{l}\text { Leishmania infantum / } \\
\text { protozoa }\end{array}$ & $\begin{array}{l}\text { sand fly } \\
\text { Phlebotominae }\end{array}$ & high / high & low / moderate & moderate / high \\
\hline $\begin{array}{l}\text { Anaplasma spp. / } \\
\text { bacteria }\end{array}$ & hard ticks & moderate / low & low /low & low / low \\
\hline $\begin{array}{l}\text { Ehrlichia canis / } \\
\text { bacteria }\end{array}$ & $\begin{array}{l}\text { hard tick } \\
\text { Rhipicephalus } \\
\text { sanguineus }\end{array}$ & moderate / high & no & no \\
\hline $\begin{array}{l}\text { Hepatozoon spp. / } \\
\text { protozoa }\end{array}$ & $\begin{array}{l}\text { hard tick } \\
\text { Rhipicephalus } \\
\text { sanguineus }\end{array}$ & moderate / low & low /low & no \\
\hline $\begin{array}{l}\text { Hemoplasma spp. / } \\
\text { bacteria }\end{array}$ & fleas & low / moderate & moderate / high & no \\
\hline $\begin{array}{l}\text { Borrelia burgdorferi } \\
\text { sensu lato / bacteria }\end{array}$ & hard ticks & low / low & no & high / moderate \\
\hline $\begin{array}{l}\text { Thelazia callipaeda / } \\
\text { helminths }\end{array}$ & fruit flies & low / low & low / low & low / low \\
\hline $\begin{array}{l}\text { Bartonella spp. / } \\
\text { bacteria }\end{array}$ & fleas & low / moderate & low / low & moderate / high \\
\hline $\begin{array}{l}\text { Dipylidium caninum / } \\
\text { helminth }\end{array}$ & fleas & moderate / low & low / low & low / low \\
\hline
\end{tabular}


Table 2. Major canine and feline VBDs and main diagnostic tests

\begin{tabular}{|c|c|c|c|c|}
\hline Pathogen disease & Antigen test & PCR & Antibody test & $\begin{array}{l}\text { Additional helpful } \\
\text { test }\end{array}$ \\
\hline $\begin{array}{l}\text { Dirofilaria immitis } \\
\text { Heartworm disease }\end{array}$ & $\begin{array}{c}\text { yes - female adult } \\
\text { protein }\end{array}$ & yes & $\begin{array}{l}\text { exposure } \\
\text { screening test } \\
\text { only in cats }\end{array}$ & heart ultrasound \\
\hline $\begin{array}{l}\text { Dirofilaria repens } \\
\text { skinworm } \\
\text { disease }\end{array}$ & No & yes & no & ultrasound \\
\hline $\begin{array}{l}\text { B. canis } \\
\text { canine babesiosis }\end{array}$ & $\begin{array}{l}\text { blood smear } \\
\text { microscopy; } \\
\text { intra-erythrocytes }\end{array}$ & yes & $\begin{array}{c}\text { yes, } \\
\text { seroconversion } \\
\text { or titer increase }\end{array}$ & $\begin{array}{l}\text { hematology, blood } \\
\text { chemistry } \\
\text { urine analysis }\end{array}$ \\
\hline $\begin{array}{l}\text { TBE-virus tick- } \\
\text { borne encephalitis }\end{array}$ & No & $\begin{array}{l}\text { yes, but in vivo } \\
\text { mostly negative }\end{array}$ & $\begin{array}{l}\text { yes, } \\
\text { seroconversion } \\
\text { or titer increase }\end{array}$ & $\begin{array}{l}\text { cerebrospinal fluid } \\
\text { analysis } \\
\text { necropsy - virus } \\
\text { detection }\end{array}$ \\
\hline $\begin{array}{l}\text { Leishmania infantum } \\
\text { leishmaniosis }\end{array}$ & $\begin{array}{l}\text { histology, } \\
\text { cytology; intra- } \\
\text { macrophagic }\end{array}$ & yes & $\begin{array}{c}\text { yes } \\
\text { exposure } \\
\text { screening }\end{array}$ & $\begin{array}{l}\text { hematology, blood } \\
\text { chemistry } \\
\text { urine analysis }\end{array}$ \\
\hline
\end{tabular}

\section{Canine babesiosis}

Canine babesiosis is a seasonal disease in Europe caused by Babesia canis in central and Eastern Europe, and Babesia vogeli in the Mediterranean area. The spatial and temporal distribution of canine cases is based on the endemic occurrence of the vector, which is Dermacentor reticulatus for B. canis and Rhipicephalus sanguineus for B. vogeli. Only adult $D$. reticulatus parasitize on dogs, whereas larvae and nymphs usually attach to small rodents. The small protozoan parasite, Babesia gibsoni, is reported in southern and Eastern Europe and it is transmitted mostly by R. sanguineus. Nowadays, it is broadly accepted that these small babesia might also be transmitted directly between hosts due to dog bite injuries, thus leading to unexpected cases, even in regions where the vector is not endemic [10].

The autochthonous distribution of $B$. canis is documented from the Iberian Peninsula to France in the west, and from Norway to Russia in the northern part of Europe [11]. In central Europe, it seems that this pathogen was introduced in the 1980s and 1990s by dogs imported from southern and eastern European countries [12,13]. After the break down of the Iron Curtain in 1989, the Austrian-Hungarian border was open for traffic and many hunters and their associated dogs frequently entered endemic areas for canine babesiosis in Hungary. In 2008, Leschnik et al. (2008) considered this disease to be endemic in large areas of Austria; $50 \%$ of cases were imported from Hungary and 50\% were already autochthonous [14].

In southeastern Europe, the distribution of B. canis partially overlaps with B. vogeli, although B. canis is responsible for the majority of canine cases [15-17]. Similar to 
Austria, also in Serbia, canine babesiosis was a sporadic infection 30-40 years ago, and it was detected only in hunting dogs and dogs after vacation in an endemic area [18]. Nowadays, this disease is frequently diagnosed, which has led to the assumption that the pathogen, as well as the vector, is broadly distributed and endemic in large areas all over Europe [14,19].

Particularly in these canine cases, where B. canis is the underlying pathogen, a typical seasonal pattern of occurrence in Europe is observed, which is assumed to be caused by the tick's activity due to local climate conditions. Dermacentor spp. is well known to tolerate low temperatures, although warm and humid conditions are preferred for the development and reproduction. These seasonal patterns differ between certain locations all over Europe. They have been described, in particular, for Hungary, Serbia, Poland and Austria [14,19-21]. Air temperature, relative humidity, atmospheric pressure and cloud cover mainly influence the activity of D. reticulatus [14,19]. Other known factors that impact on vector activity include the length of day and the daily soil temperature in the morning [22,23]. A large variety of scientific reports document the current and ongoing local and global changes of climate. Even long-term relationships between the occurrence of canine babesiosis and meteorological parameters could be observed. Climate conditions, several months before the occurrence of pathogen transmission to dogs, influence infected vector density, as well as development and survival of ticks. Because of global climate change, delayed winter climate conditions and early defrosting of soil and vegetation in the first weeks of a year activate this tick population, which results, thereafter, in direct effects on the number of clinical cases [24]. This leads to unexpected cases in dogs during the winter season, making current and quite recent climate observations more valuable when diagnosing canine babesiosis [20,24]. Another fact, based on changing climate, is a possible increase in the rodent population when winters become less cold, leading to a higher host population for larvae and nymphs of D. reticulatus [24]. Climate is also responsible for several extreme environmental conditions such as flooding of small and large rivers. In recent years, changes to the occurrence and time shifting of flooding in Europe have been reported $[25,26]$. These dramatic changes, and the increase of so-called extreme weather events, have a direct impact on host populations (rodents) as well as on tick populations.

Clinical signs caused by B. canis are variable and unspecific. Incubation time is assumed seven days to two weeks, leading to an acute onset of fever, apathy and anorexia. Hemoglobinuria and pale mucosals are the result of parasite related erythrocyte destruction. Common complications include pancreatitis, systemic inflammatory response syndrome, disseminated intravasal coagulopathy, neurological signs due to cerebral hypoxia, and especially renal failure, which is the most frequently observed cause of fatality [27]. Laboratory results from blood and urinary analysis are often indicative for canine babesiosis, especially the combination of thrombocytopenia, leukopenia and alterations in reticulocyte count [28]. Eichenberger et al. (2016) report that in B. canis infections, dogs with severe thrombocytopenia, mild to moderate 
leukopenia, hyperlactatemia, hyperphosphatemia or hyperproteinemia are more likely to die compared to patients without these alterations [29]. Systemic inflammatory response in canine babesiosis results in an increase of several blood parameters such as acute phase proteins and serum lipid concentrations, which could help to identify possible infection, as well as early diagnosis of developing complications [30,31]. Pathogen detection, as early as possible, is essential for the initiation of specific therapy with Imidocarb $(6.6 \mathrm{mg} / \mathrm{kg})$. For initial screening of suspected cases, light microscopy is the fastest and most accessible tool for practitioners, although the confirmation of the diagnosis depends on the expertise and experience of the operator. However, the sensitivity is lower than that of molecular methods making PCR an important tool to identify suspected cases where blood smear examination is negative [9,11]. Antibody detection in canine babesiosis indicates babesia exposure, but cannot discriminate what type of babesia is involved due to serological cross-reactions; nor can it confirm current infection. Seroconversion after the first infection takes more than two weeks to occur, so most acute cases will present antigen positive and antibody negative [17]. Maggi et al. (2014) report six seropositive dogs out of twelve PCR positive dogs [32]. Only in rare cases with strong clinical evidence of canine babesiosis and negative results for babesia detection (blood smear and PCR), repeated serological testing after three weeks might be useful to identify the underlying pathogen. Nevertheless, usually the decision for specific therapy is not based on these serological results, as the time span for laboratory confirmation is too long. Breed predisposition for clinical disease can be assumed due to the development of natural resistance in local breeds with frequent exposure [33]. The prevalence of specific antibodies was significantly higher in German Shepherds and Komondors in Hungary; however, there is no report on a large number of clinical canine cases allowing for calculating breed predispositions in Europe [34]. Hunting dogs have a higher risk of being infected than companion dogs $[15,35]$.

In conclusion, the diagnosis of canine babesiosis is based on the confirmation of the pathogen by blood smear light microscopy or by PCR. The underlying decisionmaking process to test for $B$. canis should rely on initial blood values in combination with clinical signs. History-based parameters such as the place of residence, use of the dog, and local climate conditions within the last three weeks before clinical signs were reported should support this decision. Additionally, the previous application of acaricidal drugs, as well as the observation of ticks on the dog by the owner, should be considered. Current studies state a whole year round risk for canine babesiosis, so veterinarians have to be aware of this common infectious disease throughout central and southeastern Europe even in unexpected seasons.

\section{Canine and feline dirofilariosis}

Dirofilariosis is an emerging, nematode infection spread by two different filarial parasites: Dirofilaria immitis causing heartworm disease in dogs and cats, and Dirofilaria repens causing skinworm disease. These nematodes are white and the adult stages range 
from approximately 10 to $30 \mathrm{~cm}$ in length [36]. Hematophagous mosquitos, mainly of the genera Aedes/Ocblerotatus, Anopheles and Culex, transmit these two nematode species. These vectors are distributed worldwide, so D. immitis is known in temperate, tropical, and subtropical areas of the world, whereas D. repens is limited to southern and eastern Europe and Asia [37]. Climate-dependent introduction of invasive and exotic mosquitos such as Aedes albopictus, which is also actively biting during the day, and Aedes japonicus are of rising importance in dirofilariosis in Europe [38,39]. Aedes japonicus has been found recently in Germany, France, Slovenia and Croatia. Every mosquito species needs specific landscape requirements for breeding sites, thus occurrence is strictly limited to these conditions. Egg deposition and larval development of Aedes japonicus take place in natural habitats, such as stream rock pools and tree holes, and in artificial containers such as plant dishes, rainwater catchments and trash cans, the latter particularly often being available near human dwellings. Despite landscape conditions and climate parameters such as temperature and humidity, wind speed and direction also influences mosquito occurrence and activity. These currently changing parameters can be integrated into a model, predicting the future situation of mosquito habitats and, thus, the occurrence of mosquito-borne infections in Europe [40].

Mosquitos are an essential part of the Dirofilaria development cycle, which makes iatrogenic or artificial transmission by blood transfusion or open wounds directly to another host impossible. After ingesting first stage larvae by the blood meal on a suitable host, these larvae must develop within the vector to larval stage 3 until they can be transmitted to a mammalian host. This part of the developmental cycle is highly dependent on environmental temperature. At $30^{\circ} \mathrm{C}$, development of microfilariae to infective L3 larvae is completed in 8-9 days, compared to 29 days at $18^{\circ} \mathrm{C}$ [41]. Once transmitted, third stage larvae develop to adult sexual nematodes by another two stages, during migration to the right heart and pulmonic arteries (D. immitis) or to subcutaneous locations (D. repens), where mating takes place.

The zoonotic situation is emerging as 1,533 cases of human dirofilariasis have been reported in Ukraine between 1975 and 2012 as a notifiable disease [42]. In other countries this reporting system has still not been established, therefore the estimated total number of unreported cases is probably much higher, as other reports count only about 1,500 cases worldwide [37]. Tasić-Otašević et al. (2015) show the increasing number of human cases in the Balkans [43]. Up until 2000, 59 cases were reported, and from 2000 to 2014, 102 human cases, including 28 cases from Serbia, were documented. For both Dirofilaria, humans are less suitable hosts compared to dogs and cats but it frequently causes subcutaneous and subconjunctival nodules (D. repens) and pulmonary disease (D. immitis) [37]. Microfilaremia is a rare event in humans, as most nematodes do not reach a vital and reproductive adult stage [43].

Canine and feline heartworm infection are found mainly in southern European countries, whereas $D$. repens infections are more common in eastern and southeastern Europe $[42,44,45]$. Tasić-Otašević et al. (2015) review canine and human Dirofilaria infections in the Balkan Peninsula, and report that the overall prevalence in dogs 
ranges from 3\% to 35\% in southeastern Europe [43]. In general, canine prevalence for $D$. immitis is much lower compared to prevalence for $D$. repens. The range for $D$. immitis in dogs, examined between 2000 and 2014, is up to $22.9 \%$, with a common range of $3-13 \%$, whereas the range for D. repens is $7-49 \%$. In 2017 , Krstic et al. (2017) present a survey on D. immitis infections in asymptomatic dogs from Serbia with $12.7 \%$ positive for microfilaria [46]. Among wild canids, the red fox (Vulpes vulpes) is an important reservoir for Dirofilaria. Adult heartworms were identified in 4 out of 83 fox carcasses in South Banat, and adult D. repens nematodes were found subcutaneously in two wolves and on a fox in Serbia and Macedonia [47,48]. Similar results for D. immitis have been obtained from highly endemic areas in Hungary, with $3.7 \%$ in foxes and $7.4 \%$ prevalence in golden jackals (Canis aureus). Canine heartworm disease has been considered endemic in Hungary since 2007; since then, the number of cases has increased dramatically [49]. Sonnberger et al. (2020) show that just by importing dogs from Hungary to Austria, the number of positive tested dogs in Austria increased by a factor of 20-30 over the last ten years [50]. The first records on autochthonous D. repens infections in Austrian dogs were published in 2009, near the border of Hungary and Slovakia; confirmation of an endemic status was achieved by the detection of skinworm DNA in mosquitos a few years later [51,52]. Interestingly, the number of cases in eastern Austria is still much lower when compared to Hungary and Slovakia, despite the very short distance between areas of high population and companion animal density (Vienna and Bratislava). Common wind conditions, such as the westerly wind and higher wind speed in the Danube Valley, could reduce the invasion of infected mosquitos, making the importation and travel of dogs the main factor for pathogen introduction. In Slovakia, the ongoing increase of the number of canine cases has also been documented. D. repens has been detected in up to $25 \%$ of dogs, especially near the border of Austria and Hungary in the southwest. In one breeding facility in southwestern Slovakia, 18 out of 25 dogs were tested positive for Dirofilaria infection [53]. In 31\% of these D. immitis positive dogs, no foreign travel history was reported; the remaining dogs had histories of travel to Italy, Hungary, Serbia and the Czech Republic. The local mosquito population revealed a prevalence for Dirofilaria of $4.26 \%$ [39].

Canine dirofilariosis occurs more often in adult dogs and in large and giant breed dogs. Shorthair and rural environment is predictive for infection. Numbers of microfilariae in the peripheral blood reach their highest levels in May and August, corresponding to activity peaks and population of vector mosquitos [54]. In a Serbian survey, the heartworm prevalence in a group of dogs from kennels was $44 \%$, and in pet dogs not receiving preventative treatment it was $60 \%$; this shows that lifestyle and owner care strongly influences infection prevalence [46]. A significant association between dirofilarial infection and the use of dogs was found for hunting dogs [55]. For cats, outdoor access and missing preventive treatment, such as in stray cats, are considered predictive parameters for infection [56]. No gender predilection has been observed in naturally exposed cats [57]. 
Clinical signs in heartworm infections are caused by the presence of adult nematodes in the right heart, the pulmonary arteries and more seldom in the caval veins, as well as by the release of Wolbachia spp., endosymbiontic bacteria. Cats are considered susceptible but resistant hosts to the infection, compared to dogs. The feline infection rate is estimated to be 5 to $20 \%$ of the canine infection rate in the corresponding local population [56]. Adult nematodes survive a shorter period and aberrant migration occurs more often in cats than in dogs [57]. In cats, D. immitis infection induces severe pulmonary airway, interstitial and arterial lung lesions by immature adult stages leading to tachypnea, dyspnea, coughing and vomiting. Thus, clinical signs may develop even when nematodes die before completing maturation [58]. Thereafter, adult Dirofilaria seem to suppress feline immune responses and clinical signs may disappear or become atypical. Dying heartworms induce pulmonary inflammation and thromboembolism, inducing acute respiratory signs. In cats, a combination of several tests is recommended to diagnose heartworm disease. Initially, thoracic X-ray examination and a serum antibody test should be done for screening and, thereafter, echocardiography and a serum antigen test to confirm the infection [57]. Temporal variable blood eosinophilia and inconsistent basophilia has been noted in infected cats. Bronchoalveolar lavage analysis also frequently demonstrates eosinophilia [58]. Microfilaremia is rarely observed in cats and it mostly remains an incidental finding. Radiographic changes include enlargement of pulmonary arteries and truncation in the caudal lobar branches. Diffuse or focal bronchointerstitial parenchymal patterns are another feature, but are also recognized in feline asthma and lungworm infection. Echocardiography can visualize adult nematodes within the right heart or adjacent pulmonary arteries as double-lined hyperechoic structures [57].

Dogs are considered the main reservoir, and many transmitted larvae develop to vital adult nematodes. The prepatency period is the time between vector-borne infection with L3 larvae and the occurrence of L1 larvae in the peripheral blood, which is around six months. Therefore, dogs without heartworm prophylaxis should be tested at least once six months after leaving an endemic area to rule out infection. Depending on the worm burden, clinical signs are variable and range from asymptomatic to severe exercise independent respiratory distress and weakness. Stage 1 is observed in most dogs, and patients without obvious signs or just mild exercise dependent coughing are included. Dogs with chronic coughing, sometimes even during resting, and low exercise tolerance are allocated to stage 2 . Stage 3 presents dogs with severe clinical signs and distinct changes in thoracic X-ray and cardiac ultrasonography. Congestion signs such as abdominal and thoracic effusion, enlarged liver and spleen can occur, and pulmonary hypertension is observed frequently in these dogs. The end stage includes dogs with acute caval syndrome with poor prognosis [59].

Diagnostic procedures in dogs are even based on an initial screening by antigen test or microfilaria detection (Knott test or blood smear), or on an incidental finding of adult worms in a cardiac ultrasonography or larvae in a blood smear. An antigen test is highly specific and sensitive for D. immitis infection and detects a protein from the 
female fertile nematodes. Therefore, the test might be a false negative in the case of only male worm infection, which can also produce no microfilariae. A controversy has evolved regarding the heat treatment of canine and feline serum prior to antigen testing. It is assumed that, in some cases, antibodies block the antigen, and so it cannot bind to the testing site in the antigen test, which could also lead to false negative results. It has been demonstrated that heat pre-treatment could release the blocked antigen, thus antigen test results become positive. Others state that the pre-heating the serum sample could reduce specificity, producing false positive results [60,61]. Hematological and serum chemical abnormalities may display mild anemia (10-60\%, depending on the severity of affection), neutrophilia (20-80\%), eosinophilia (85\%) and basophilia (60\%). As soon as congestion signs are present, liver enzymes might increase. Hyperbilirubinemia and azotemia, as well as albuminuria, are rarely observed [36].

D. repens, the causative agent of cutaneous dirofilariosis, seems to spread much faster from southern to northern Europe compared to D. immitis [44]. Prevalence in some central European dog populations is up to $52.9 \%$, and zoonotic potential is much greater than that of D. immitis $[62,63]$. This increases concerns about this parasitic infection, and thus it is named an emerging zoonosis [44]. After transmission by mosquitos, infection becomes patent 6-10 months later, and adult parasites can live 2-4 years in the subcutaneous tissue of dogs. Tarello (2011) describes pruritus, nodules and other dermatological signs [64]. Many infected dogs remain undetected due to the subclinical status of the infection; therefore, $43 \%$ of canine cases are identified by coincidence in blood smears, cytological preparations or during surgery [50]. Differentiation of microfilariae, from both Dirofilaria species, should be done by PCR. Adult worms can be specified by special staining or even by PCR. Subcutaneous nodules are $1-3 \mathrm{~cm}$ in diameter and ultrasonographic examination reveals double linear parallel hyperechoic structures that are sometimes moving. Risk factors in dogs include the lack of preventive measures and kenneled dogs, older age, male gender, rural environment and geographic location of residence [44].

In conclusion, the diagnosis of dirofilariosis depends on the awareness of veterinary practitioners as most infected animals show no or just minor and unspecific clinical signs. Therefore, history-based parameters, such as the place of residence as well as the use, age and lifestyle of the pet at any time in its life before, should support the decision to test the animal. In dogs, a screening test for D. immitis is the antigen test for female adult worms. Microfilariae can be detected in the blood smear or by modified Knott's test. Discrimination of microfilariae (D. immitis versus D. repens) should be done by PCR. In cats, antibody testing is the major tool to identify infected animals as microfilaremia is seldom. An antigen test may confirm current infection by adult female nematodes. Thoracic X-ray is necessary to evaluate the severity of organic changes in D. immitis infection, and heart ultrasonography could visualize the nematodes. In subcutaneous nodules, $D$. repens may also be identified as nematode by ultrasound. Additionally, the previous application of insecticidal or repellent drugs, as 
well as heartworm prophylaxis by macrocyclic lactones, should be taken into account. On the author's opinion, we are heading for a situation where large scale screening of our canine population as well as standardized prophylactic measures become the only tools to reduce the infection risk for pet animals and humans as well.

\section{Canine and feline leishmaniosis}

Canine and feline leishmaniosis have gained much attention in recent years as the underlying pathogen has a major zoonotic potential. In particular, canine case numbers are currently increasing in many regions of Europe [65]. The domestic dog is considered as an indicator for the presence of this pathogen in a certain area, as it is the main reservoir of L. infantum [66]. Leishmania infantum is transmitted by several blood sucking sand fly species, thus regional occurrence is mainly based on the presence of these arthropods. A low proportion of sand flies, up to 3\% harboring the pathogen, is sufficient to maintain the infection cycle in endemic areas [67]. Many Mediterranean countries including France, Greece, Spain, Italy, Cyprus and Turkey, as well as Portugal have been endemic with canine and human leishmaniasis for many years [68]. In several Central European countries, this infection in now diagnosed frequently in imported dogs from southern and eastern European countries, posing the possible future risk of this pathogen becoming endemic in these regions $[9,69,70]$. Until now, the origin of infection in a few canine cases from Germany remains unclear, as no travel history was present, whereas in Austria all infected dogs could be assigned to a travel history or an origin from endemic countries $[9,69]$. The Alps seem to be a natural barrier to the direct northward spread of sand flies, although some of these species have been found up to 3300 meters above sea level in Asia [71]. A possible natural gate for the vector expansion from southern areas to central Europe remains the Alpine-Carpathian gap between Vienna and Bratislava, where sand flies were identified and cases could be expected in the near future [72]. Especially in southeastern Europe, L. infantum has been found recently in Phlebotomus spp. and dogs. Further, autochthonous canine cases have been reported in Hungary, Bulgaria, and Romania, which underline the emerging nature of this spreading infection [15,73-77]. In northern areas of Italy, at the foothills of the Alps, new endemic foci have been identified [78].

In Serbia, leishmaniosis was endemic and sand flies were present during the middle of the twentieth century. After 1968, the disease was considered to be eradicated; however, a recent report on the disease, in humans and dogs, gives rise to the concern that the vectors and the pathogen have been reintroduced [79]. As a major zoonosis, human migration might also act as a contributing factor in spreading the disease. Known human migration routes used by East-Mediterranean and Middle-Eastern refugees, from 2015 on, as well as tourists and trade transit routes in Serbia, have been identified and a survey on the presence of sand flies and Leishmania spp. was conducted. Several Phlebotomus spp. were identified and most of them showed vector-competence for the development and transmission of Leishmania infantum [79]. In the Serbian province of Vojvodina, adjacent to Hungary in the north, autochthonous cases in dogs and 
L. infantum DNA in sand flies were reported [73]. In southern Hungary, this disease was documented for the first time in 2007 [75]. Collela et al., (2019) reported PCR positive dogs in the central and southern part of Bosnia and Herzegovina (Sarajevo and Mostar), and antibody positive dogs throughout the country [74]. In Croatia, seropositive dogs were identified in Dubrovnik, near the Bosnian border, and in southern Dalmatia, up to Split in the north $[15,80]$. In Albania and Kosovo, dogs were tested positive by PCR as well as serologically, thus completing the current picture of the ongoing spread of Leishmania spp. distribution in the Balkan region [81]. Climate change certainly influences arthropod prevalence; interestingly, several studies pose positive associations more often for regional and national studies as in a global or zonal context. Increasing, mean annual temperature in specific areas is one explanation for Phlebotomus spp. occurrence; however, this correlation is not linear, as high temperatures can also result in reduced survivorship, especially when rainfall and moisture is also lower [5].

Despite vector-based transmission, several other ways of transmission have been proven in dogs: horizontal transmission by blood transfusion and mating as well as vertical transmission from the infected dam to the offspring [82].

Canine breed susceptibility is based on genetic predispositions. Ibizan hound dogs usually develop a more cellular immunity-based response, which leads to a higher tendency of natural resistance. Some dog breeds such as the Boxer, Cocker Spaniel, Rottweiler and German Shepherd show a higher level of susceptibility, leading more frequently to clinical signs [67]. In Boxer dogs, horizontal and vertical transmission, without the presence of a competent vector, has been reported in non-endemic areas [83]. Genetic markers can explain genetic variance in both pro- and anti-inflammatory cytokines and cellular immune response, so that even within a certain breed, a high variability of susceptibility is present [66]. Age seems to be another important factor as the highest prevalence is reported in dogs younger than three years and older than eight years [67].

Cats play a minor role in the transmission cycle, but they can also act as a reservoir. Especially in endemic areas, seroreactivity in stray cats ranges from $30 \%$ to $68.5 \%$ in Italy, and 60\% in owned cats in Spain $[84,85]$. Compared to dogs, the prevalence of infection is generally lower and clinical cases are less frequently reported. Feline natural resistance is more effective than in dogs and feline coinfections and comorbidities are frequently detected in cats with clinical leishmaniosis [86]. Predisposition for feline leishmaniosis is an outdoor lifestyle, rural habitat, male gender and adult aged [85].

Once transmitted during the vector's blood meal, the pathogen is attacked by the host's immune system. Pathogen elimination by the host is possible in the very early course of infection by neutrophil phagocytosis; however, once the pathogen has spread via the blood circulation, systemic disease in dogs and cats is highly likely [87]. Clinical signs in this chronic progressive disease in dogs and cats are rather similar, but they are highly variable and include many organ manifestations. Cutaneous signs 
of ulcerative, exfoliative and nodular dermatitis are frequently described in both species. Onychogriphosis and hyperkeratosis seem to be unique features of canine leishmaniosis. Ocular lesions such as keratoconjunctivitis and uveitis as well as systemic lymphadenopathy, splenomegaly, weight loss and pale mucosal membranes are described in cats and dogs. Additionally, dogs show lameness, masticatory muscle atrophy and pathogen invasion of the central nervous system, resulting in progressive neurological signs. In cats, stomatitis and glossitis are described [85]. Clinical signs are detectable in any combination. Laboratory results depend on the stage of the disease, but alterations are similar in cats and dogs. Any kind and combination of cytopenia is usually not regenerative and total protein can be elevated by marked hyperglobulinemia, despite low albumin levels. Proteinuria and, later on, azotemia are typical features of feline and canine leishmaniosis $[67,85,86]$.

Diagnostic procedures are based on the clinical history, possible pathogen exposure (vectorial or non-vectorial), and either a positive antibody test result or pathogen detection, as well as DNA detection by PCR. It is important to distinguish between infected dogs with positive antibody titers without any clinical sign, and sick dogs with clinical signs and clinicopathological abnormalities. Initial laboratory examinations include hematological and biochemical analyses, as well as urinary analysis, as some animals show altered parameters in blood or urinary analysis without evidence of obvious clinical signs. A thorough clinicopathological, individually adapted examination, has to be done in each patient to exclude other VBDs and co-infections depending on origin and history. The second step is a serological screening for antibodies by ELISA or IFAT; immunochromatography-based assays are easy to use and results are available within minutes, but sensitivity is still not optimal. Positive serological testing proves exposure and infection, although low or borderline titers should be retested after 4-6 weeks to confirm persistent infection. Negative antibody test results do not rule out infection. In non-endemic areas, imported dogs have to be tested twice after importation at an interval of six months to rule out infection as time for seroconversion can be several months. The third step is the confirmation of the presence of the pathogen. This can be done by highly sensitive PCR from body fluid (blood, cerebrospinal fluid, synovia and bone marrow) or tissue such as skin, lymph node, spleen, or conjunctival swabs. In endemic areas, positive PCR from skin samples, without any clinical signs, could be misleading in terms of proving persistent infection and, therefore, should be interpreted with caution. Cytology preparations of skin scrapings, lymph node or spleen aspirations or any kind of body fluid could make Leishmania spp. amastigotes visible in macrophages in the microscopic examination [67,85].

In conclusion, the diagnosis of canine and feline leishmaniosis is based on the initial screening for specific antibodies and confirmation of the pathogen in body fluids or aspirates as well as tissue samples by PCR or light microscopy. The underlying decisionmaking process to test for leishmaniosis should rely on initial blood and urinary values in combination with clinical signs. History-based parameters such as the place of 
residence, as well as use and lifestyle of the pet at any time in its prior life, should support this decision. Age, gender and breed are known to be predisposing factors for disease, but might not be for infection. Additionally, the previous application of insecticidal or repellent drugs, as well as anti-Leishmania vaccinations, should be taken into consideration. In the light of the progressive spread of the vector, the pathogen, and infected hosts, it becomes more likely to identify infected animals by antibody testing, but more difficult to decide which one should be put on extensive and expensive therapy because of sometimes unspecific clinical signs.

\section{Canine tick-borne encephalitis}

Tick-borne encephalitis (TBE) is a Flavivirus-induced and VBD causing a large number of human cases, including fatalities, in Europe and Asia as well as long-term consequences and socioeconomical impact. The main vector is Ixodes ricinus in Europe as well as $D$. reticulatus, whose significance is inexplicit for humans but certainly relevant for dogs [88]. TBE virus transmission to dogs is a frequent event in endemic areas with a calculated annual risk of about $11.6 \%$ [4]. This tick-borne infection infrequently causes encephalitis in dogs, with a possible fatal outcome, but does not cause clinical signs in cats [89-91]. Tick-borne encephalitis has expanded to northern Europe and the occurrence of the main vector has been observed in higher altitudes in central Europe in the last decade $[92,93]$. The increasing vertical distribution of infected ticks, and the resulting clinical cases, is attributed to changing climate [94]. Increasing tick activity in I. ricinus during winter months has been attributed to short periods of time with temperatures suitable for the vectors; thus, single cases of TBE have been observed during winter seasons in dogs [95,96]. In humans, TBE is also transmitted by consumption of raw milk from infected and viraemic cattle, sheep or goats. One canine case from the Czech Republic described a TBE-infection after consumption of raw goat milk [97].

Canine seroprevalence in central and northern endemic European countries is reported as $19.9 \%$ in Austria, 28\% in healthy dogs and 54\% in ill dogs in Germany, and 16.4\% in Norway [98-100]. In Serbia, $17.5 \%$ of tested dogs had specific antibodies, indicating frequent exposure to this pathogen [101]. Breed predisposition remains open due to the low total number of published cases; however, Rottweilers and Siberian Huskies seem to be over-represented. Another noticeable fact is the invariable adult age of affected dogs as no puppies have been reported to suffer from TBE. Sled dogs and hunting dogs are supposed to have more frequent exposure times to infected vectors than dogs without this level of outdoor access [4,102].

Transmission to the host occurs within the first hours during the tick's blood meal, as the virus is located in the tick's salivary glands. The incubation period is estimated as five to nine days. An acute onset of clinical symptoms, leading to the maximal intensity of neurological signs within 48 hours, is typical for this disease. Initially, most dogs are depressed and show unspecific signs, such as salivation, vomiting and 
refusing feeding, and are reluctant to move due to generalized weakness. Some dogs present with compulsive walking, circling to one side, and unusual behavior $[89,90,97]$. Elevated body temperature may initially be addressed as fever; later on, it is more likely a result of non-voluntary excessive muscle contraction (e.g., seizures, loss of inhibition by upper motor neuron damage). Seizures are a principal result of cerebral damage due to TBE and observed in up to $1 / 3$ of canine cases. In particular, blindness due to papillitis, optic nerve inflammation or chiasma opticus neuritis may become a dominant symptom. In these cases, visual deficits are the major clinical sign and result from detachment of the peripapillary retina, peripapillary hemorrhages and inflammatory edema [95]. Degeneration and demyelination of cranial nerves is initiated by the virus's neurotropism; later on, secondary immune reaction to neural tissue may prolong the period of damage and lead to irreversible symptoms such as retinal and optic disc atrophy. Other cranial nerve deficits such as trigeminal dysfunction, resulting in reduced facial sensation and chewing muscle atrophy, vestibular signs (nystagmus and positional strabismus) and facial palsy are observed. Major involvement of the spinal cord results in mostly symmetrical paresis, muscle twitching and proprioceptive dysfunction, which may also be present as an exclusive symptom and may occur asymmetrically $[90,97]$.

It is essentially important to consider differentials such as rabies, distemper and Aujeszky's disease at that time. Fatalities usually occur within the first week of disease and are supposed to be caused by the inability to clear the virus from the dog's brain by local immune response. Inflammatory changes of cerebrospinal fluid (CSF) usually include lymphocytic pleozytosis and elevated total protein. The tentative diagnosis is based on the presence of specific serological or intrathecal antibodies as well as increasing or decreasing titers within one to two weeks [90]. Virus detection in the CSF intra vitam is seldom found due to fast virus clearance; therefore, pathogen detection is usually achieved by postmortem brain preparations [103]. Magnetic resonance imaging findings include bilateral and symmetrical gray matter lesions involving the thalamus, hippocampus, brain stem, basal nuclei and ventral horn on the spinal cord. All lesions have minimal or no mass effect or perilesional edema [104]. These findings are comparable to the distribution of lesions in the canine brain detected by necropsy and immunohistochemistry [103]. A previous application of acaricidal drugs, as well as the observation of ticks on the dog 5-10 days before symptoms occurred, should be considered; however, $25 \%$ of dog owners are not able to identify and report tick infestation in their dogs with sufficient certainty [4].

In conclusion, the tentative diagnosis of canine TBE intra vitam is based on clinical symptoms and the confirmation of specific serological or intrathecal antibodies. The underlying decision-making process to test for TBE-antibodies should rely on historybased parameters such as residence in an endemic area. Local climate conditions, within the last 10 days before the onset of clinical signs, favorable for tick activity, should support this decision. The age and breed of the dog should not influence this decision, as the number of published canine patients is too low to identify these 
parameters as significant predisposing factors. Tick-borne encephalitis is the only viral encephalitis in dogs that does not always result in a fatal outcome. Despite severe neurological signs, it is worth to undertake diagnostic measures and put them on symptomatic therapy.

\section{CONCLUSION}

Diagnostic procedures in companion animal infectious diseases are well investigated and described in scientific papers as well as in several textbooks for veterinary medicine. Research has focused on predisposing factors for the occurrence of disease as well as vectors and pathogens. These parameters are animal related, for example, age, breed and gender, as well as lifestyle and use of prophylactic measures. Environmental parameters such as climate, vector and host densities can give additional information, even for veterinary practitioners, which could help to decide on further diagnostic work-up. Keeping professional knowledge about these developing and changing parameters up-to-date is a challenge and may be a new requirement for veterinary practitioners.

\section{Authors' contributions}

LM was responsible for conception, acquisition of data, analysis, interpretation, drafting and revising the manuscript.

\section{Declaration of conflicting interests}

The author(s) declared no potential conflicts of interest with respect to the research, authorship, and/or publication of this article.

\section{REFERENCES}

1. The European Pet Food Industry Federation: Facts \& Figures 2018, The European Pet Food Industry Federation. [https://www.fediaf.org]

2. Stone K: Animal Pharmaceutical Companies - Sales and Marketing 2019. The Balance. com. [https://www.thebalance.com/of-the-largest-animal-pharmas-2663221]

3. World Health Organization: Vector-borne Diseases 2017. World Health Organization, Geneva. [https://www.who.int/en/news-room/fact-sheet/detail/vector-borne-diseases]

4. Leschnik M, Feiler A, Duscher GG, Joachim A: Effect of owner-controlled acaricidal treatment on tick infestation and immune response to tick-borne pathogens in naturally infested dogs from Eastern Austria. Parasit Vectors 2013, 6:62.

5. Franklinos LHV, Jones KE, Redding DW, Abubakar I: The effect of global change on mosquito-borne disease. Lancet Infect Dis 2019, 19:e302-e312.

6. Semenza JC, Suk JE: Vector-borne diseases and climate change: a European perspective. FEMS Microbiol Letters 2018, 365:fnx244. 
7. Mircean V, Dumitrache MO, Györke A, Pantchev N, Jodies R, Mihalca AD, Cozma V: Seroprevalence and geographic distribution of Dirofilaria immitis and tick-borne infections (Anaplasma phagocytophilum, Borrelia burgdorferi sensu lato, and Ehrlichia canis) in dogs from Romania. Vector Borne Zoonotic Dis 2012, 12:595-604.

8. Irwin PJ: It shouldn't happen to a $\operatorname{dog} \ldots$ or a veterinarian: clinical paradigms for canine vector-borne diseases. Trends Parasitol 2014, 30:104-112.

9. Vrhovec MG, Pantchev N, Failing K, Bauer C, Travers-Martin N, Zahner H: Retrospective Analysis of Canine Vector-borne Diseases (CVBD) in Germany with Emphasis on the Endemicity and Risk Factors of Leishmaniosis. Parasitol Res 2017, 116(Suppl 1):131-144.

10. Imre M, Farkas R, Ilie MS, Imre K, Dărăbuş G: Survey of babesiosis in symptomatic dogs from Romania: occurrence of Babesia gibsoni associated with breed. Ticks Tick Borne Dis 2013, 4:500-502.

11. Solano-Gallego L, Sainz Á, Roura X, Estrada-Peña A, Miró G: A review of canine babesiosis: the European perspective. Parasit Vectors 2016, 9:336.

12. Hinaidy HK, Tschepper P: Babesia canis in a dog in Austria. Wien Tierärztl Mschr 1979, 66:302-304.

13. Schwendenwein I: Canine babesiosis in Austria - review of clinical presentation, diagnosis and therapy with reference to four cases. Wien Tierärztl Mschr 1989, 76:161-164.

14. Leschnik M, Kirtz G, Tichy A, Leidinger E: Seasonal occurrence of canine babesiosis is influenced by local climate conditions. Int J Med Microbiol 2008, 298:243-248.

15. Mrljak V, Kuleš J, Mihaljević Ž, Torti M, Gotić J, Crnogaj M, Živičnjak T, Mayer I, Šmit I, Bhide M, Barić Rafaj R: Prevalence and Geographic Distribution of Vector-Borne Pathogens in Apparently Healthy Dogs in Croatia. Vector Borne Zoonotic Dis 2017, 17:398-408.

16. Duh D, Tozon N, Petrovec M, Strasek K, Avsic-Zupanc T: Canine babesiosis in Slovenia: molecular evidence of Babesia canis canis and Babesia canis vogeli. Vet Res 2004, 35:363368.

17. Kovačević Filipović MM, Beletić AD, Ilić Božović AV, Milanović Z, Tyrrell P, Buch J, Breitschwerdt EB, Birkenheuer AJ, Chandrashekar R: Molecular and serological prevalence of Anaplasma phagocytophilum, A. platys, Ehrlichia canis, E. chaffeensis, E. ewingii, Borrelia burgdorferi, Babesia canis, B. gibsoni and B. vogeli among clinically healthy outdoor dogs in Serbia. Vet Parasitol Reg Stud Reports 2018, 14:117-122.

18. Gabrielli S, Otašević S, Ignjatović A, Savić S, Fraulo M, Arsić-Arsenijević V, Momčilović S, Cancrini G: Canine babesiosis in noninvestigated areas of Serbia. Vector Borne Zoonotic Dis 2015, 15:535-538.

19. Janjić F, Sarvan D, Tomanović S, Ćuk J, Krstić V, Radonjić V, Kovačević Filipović M, Ajtić $\mathrm{J}$ : A short-term and long-term relationship between occurrence of acute canine babesiosis and meteorological parameters in Belgrade, Serbia. Ticks Tick Borne Dis 2019, 10:101273.

20. Hornok S: Allochronic seasonal peak activities of Dermacentor and Haemaphysalis spp. under continental climate in Hungary. Vet Parasitol 2009, 163:366-369.

21. Welc-Faleciak R., Rodo A., Sinski E., Bajer A: Babesia canis and other tick-borne infections in dogs in Central Poland. Vet Parasitol 2009, 166:191-198.

22. Bogdaszewska Z: Range and ecology of Dermacentor reticulatus (Fabricius, 1794) in Mazuria focus. III. The influence of temperature and day length on the activity of hungry adult ticks in laboratory conditions. Wiad. Parazytol 2004, 50: 739-745. 
23. Hubalek Z., Halouzka J, Juricova Z: Host-seeking activity of ixodid ticks in relation to weather variables. J Vector Ecol 2003, 28:159-165.

24. Hartelt K, Pluta S, Oehme R, Kimmig P: Spread of ticks and tick-borne diseases in Germany due to global warming. Parasitol Res 2008, 103(Suppl.1):109-116.

25. Blöschl G, Hall J, Parajka J, Perdigão RAP, Merz B, Arheimer B, Aronica GT, Bilibashi A, Bonacci O, Borga M, Čanjevac I, Castellarin A, Chirico GB, Claps P, Fiala K, Frolova N, Gorbachova L, Gül A, Hannaford J, Harrigan S, Kireeva M, Kiss A, Kjeldsen TR, Kohnová S, Koskela JJ, Ledvinka O, Macdonald N, Mavrova-Guirguinova M, Mediero L, Merz R, Molnar P, Montanari A, Murphy C, Osuch M, Ovcharuk V, Radevski I, Rogger M, Salinas JL, Sauquet E, Šraj M, Szolgay J, Viglione A, Volpi E, Wilson D, Zaimi K, Živković N. Changing climate shifts timing of European floods. Science 2017, 357:588-590.

26. Blöschl G, Hall J, Viglione A, Perdigão RAP, Parajka J, Merz B, Lun D, Arheimer B, Aronica GT, Bilibashi A, Boháč M, Bonacci O, Borga M, Čanjevac I, Castellarin A, Chirico GB, Claps P, Frolova N, Ganora D, Gorbachova L, Gül A, Hannaford J, Harrigan S, Kireeva M, Kiss A, Kjeldsen TR, Kohnová S, Koskela JJ, Ledvinka O, Macdonald N, Mavrova-Guirguinova M, Mediero L, Merz R, Molnar P, Montanari A, Murphy C, Osuch M, Ovcharuk V, Radevski I, Salinas JL, Sauquet E, Šraj M, Szolgay J, Volpi E, Wilson D, Zaimi K, Živković N: Changing climate both increases and decreases European river floods. Nature 2019, 573:108-111.

27. Máthé A, Vörös K, Papp L, Reiczigel J: Clinical manifestations of canine babesiosis in Hungary (63 cases). Acta Vet Hung 2006, 54:367-385.

28. Kirtz G, Leschnik M, Hooijberg E, Tichy A, Leidinger E: In-clinic laboratory diagnosis of canine babesiosis (Babesia canis canis) for veterinary practitioners in Central Europe. Tierarztl Prax Ausg K Kleintiere Heimtiere 2012, 40:87-94.

29. Eichenberger RM, Riond B, Willi B, Hofmann-Lehmann R, Deplazes P: Prognostic Markers in Acute Babesia canis Infections. J Vet Intern Med 2016, 30:174-182.

30. Milanović Z, Ilić A, Andrić JF, Radonjić V, Beletić A, Filipović MK: Acute-phase response in Babesia canis and Dirofilaria immitis co-infections in dogs. Ticks Tick Borne Dis 2017, 8:907-914.

31. Milanović Z, Vekić J, Radonjić V, Ilić Božović A, Zeljković A, Janac J, SpasojevićKalimanovska V, Buch J, Chandrashekar R, Bojić-Trbojević Ž, Hajduković L, Christopher MM, Kovačević Filipović M: Association of acute Babesia canis infection and serum lipid, lipoprotein, and apoprotein concentrations in dogs. J Vet Intern Med 2019, 33:1686-1694.

32. Maggi RG, Birkenheuer AJ, Hegarty BC, Bradley JM, Levy MG, Breitschwerdt EB: Comparison of serological and molecular panels for diagnosis of vector-borne diseases in dogs. Parasit Vectors 2014, 7:127.

33. Pernzhorn BL: Why is Southern African canine babesiosis so virulent? An evolutionary perspective. Parasit Vectors 2011, 4:51.

34. Hornok S, Edelhofer R, Farkas R: Seroprevalence of canine babesiosis in Hungary suggesting breed predisposition. Parasitol Res 2006, 99:638-642.

35. Imre M, Farkas R, Ilie MS, Imre K, Hotea I, Morariu S, Morar D, Dărăbuş G: Seroprevalence of Babesia canis infection in clinically healthy dogs from western Romania. J Parasitol 2013, 99:161-163.

36. Bowman DD, Atkins CE: Heartworm biology, treatment, and control. Vet Clin North Am Small Anim Pract 2009, 39:1127-1158.

37. Fuehrer HP, Auer H, Leschnik M, Silbermayr K, Duscher G, Joachim A: Dirofilaria in Humans, Dogs, and Vectors in Austria (1978-2014)-From Imported Pathogens to the Endemicity of Dirofilaria repens. PLoS Negl Trop Dis 2016, 10:e0004547. 
38. Silaghi C, Beck R, Capelli G, Montarsi F, Mathis A: Development of Dirofilaria immitis and Dirofilaria repens in Aedes japonicus and Aedes geniculatus. Parasit Vectors 2017, 10:94.

39. Čabanová V, Miterpáková M, Valentová D, Blažejová H, Rudolf I, Stloukal E, Hurníková Z, Dzidová M: Urbanization impact on mosquito community and the transmission potential of filarial infection in central Europe. Parasit Vectors 2018, 11:261.

40. Kerkow A, Wieland R, Koban MB, Hölker F, Jeschke JM, Werner D, Kampen H: What makes the Asian bush mosquito Aedes japonicus japonicus feel comfortable in Germany? A fuzzy modelling approach. Parasit Vectors 2019 12:106.

41. Sassnau R, Daugschies A, Lendner M, Genchi C: Climate suitability for the transmission of Dirofilaria immitis and D. repens in Germany. Vet Parasitol 2014, 205:239-245.

42. Sałamatin RV, Pavlikovska TM, Sagach OS, Nikolayenko SM, Kornyushin VV, Kharchenko VO, Masny A, Cielecka D, Konieczna-Sałamatin J, Conn DB, Golab E: Human dirofilariasis due to Dirofilaria repens in Ukraine, an emergent zoonosis: epidemiological report of 1465 cases. Acta Parasitol 2013, 58:592-598.

43. Tasić-Otašević SA, Trenkić Božinović MS, Gabrielli SV, Genchi C: Canine and human Dirofilaria infections in the Balkan Peninsula. Vet Parasitol 2015, 209:151-156.

44. Capelli G, Genchi C, Baneth G, Bourdeau P, Brianti E, Cardoso L, Danesi P, Fuehrer HP, Giannelli A, Ionică AM, Maia C, Modrý D, Montarsi F, Krücken J, Papadopoulos E, Petrić D, Pfeffer M, Savić S, Otranto D, Poppert S, Silaghi C: Recent advances on Dirofilaria repens in dogs and humans in Europe. Parasit Vectors 2018, 11:663.

45. Genchi C, Rinaldi L, Cascone C, Mortarino M, Cringoli G: Is heartworm disease really spreading in Europe? Vet Parasitol 2005, 133:137-148.

46. Krstić M, Gabrielli S, Ignjatović M, Savić S, Cancrini G, Ranđelović G, Momčilović S, Stojnev S, Otašević S: An appraisal of canine and human cases reveals an endemic status of dirofilariosis in parts of Serbia. Mol Cell Probes 2017, 31:37-41.

47. Cirović D, Penezić A, Pavlović I, Kulišić Z, Cosić N, Burazerović J, Maletić V: First records of Dirofilaria repens in wild canids from the region of Central Balkan. Acta Vet Hung 2014, 62:481-488.

48. Gavrilović P, Dobrosavljević I, Vasković N, Todorović I, Živulj A, Kureljušić B, Pavlović I: Cardiopulmonary parasitic nematodes of the red fox (Vulpes vulpes) in Serbia. Acta Vet Hung 2019, 67:60-69.

49. Tolnai Z, Széll Z, Sproch Á, Szeredi L, Sréter T: Dirofilaria immitis: an emerging parasite in dogs, red foxes and golden jackals in Hungary. Vet Parasitol 2014, 203:339-342.

50. Sonnberger K, Duscher G.G., Fuehrer HP, Leschnik M: Current trends in canine dirofilariosis in Austria - do we face a pre-endemic status? Parasitol Res 2020, 119:10011009.

51. Duscher G, Feiler A, Wille-Piazzai W, Bakonyi T, Leschnik M, Miterpáková M, Kolodziejek J, Nowotny N, Joachim A: Detection of Dirofilaria in Austrian dogs. Berl Munch Tierarztl Wochenschr 2009, 122:199-203.

52. Silbermayr K, Eigner B, Joachim A, Duscher GG, Seidel B, Allerberger F, Indra A, Hufnagl P, Fuehrer HP: Autochthonous Dirofilaria repens in Austria. Parasit Vectors 2014, 7:226.

53. Miterpáková M, Valentová D, Čabanová V, Berešíková L': Heartworm on the rise-new insights into Dirofilaria immitis epidemiology. Parasitol Res 2018, 117:2347-2350.

54. Miterpáková M, Iglódyová A, Čabanová V, Stloukal E, Miklisová D: Canine dirofilariosis endemic in Central Europe-10 years of epidemiological study in Slovakia. Parasitol Res 2016, 115:2389-2395. 
55. Gizzarelli M, Foglia Manzillo V, Ciuca L, Morgoglione ME, El Houda Ben Fayala N, Cringoli G, Oliva G, Rinaldi L, Maurelli MP: Simultaneous Detection of Parasitic Vector Borne Diseases: A Robust Cross-Sectional Survey in Hunting, Stray and Sheep Dogs in a Mediterranean Area. Front Vet Sci 2019, 6:288.

56. Diakou A, Soubasis N, Chochlios T, Oikonomidis IL, Tselekis D, Koutinas C, Karaiosif R, Psaralexi E, Tsouloufi TK, Brellou G, Kritsepi-Konstantinou M, Rallis T: Canine and feline dirofilariosis in a highly enzootic area: first report of feline dirofilariosis in Greece. Parasitol Res 2019, 118:677-682.

57. Venco L, Marchesotti F, Manzocchi S: Feline heartworm disease: A'Rubik's-cube-like' diagnostic and therapeutic challenge. J Vet Cardiol 2015, 17(Suppl 1):S190-201.

58. Dillon AR, Blagburn BL, Tillson M, Brawner W, Welles B, Johnson C, Cattley R, Rynders P, Barney S: Heartworm-associated respiratory disease (HARD) induced by immature adult Dirofilaria immitis in cats. Parasit Vectors 2017, 10(Suppl 2):514.

59. Polizopoulou ZS, Koutinas AF, Saridomichelakis MN, Patsikas MN, Leontidis LS, Roubies NA, Desiris AK: Clinical and laboratory observations in 91 dogs infected with Dirofilaria immitis in northern Greece. Vet Rec 2000, 146:466-469.

60. Venco L, Manzocchi S, Genchi M, Kramer LH: Heat treatment and false-positive heartworm antigen testing in ex vivo parasites and dogs naturally infected by Dirofilaria repens and Angiostrongylus vasorum. Parasit Vectors 2017, 10(Suppl 2):476.

61. Little S, Saleh M, Wohltjen M, Nagamori Y: Prime detection of Dirofilaria immitis: understanding the influence of blocked antigen on heartworm test performance. Parasit Vectors 2018, 11:186.

62. Demiaszkiewicz AW, Polańczyk G, Osińska B, Pyziel AM, Kuligowska I, Lachowicz J, Sikorski A: The prevalence and distribution of Dirofilaria repens in dogs in the Mazovian Province of central-eastern Poland. Ann Agric Environ Med 2014, 21:701-704.

63. Genchi C, Kramer L: Subcutaneous dirofilariosis (Dirofilaria repens): an infection spreading throughout the old world. Parasit Vectors 2017, 10(Suppl 2):517.

64. Tarello W: Clinical Aspects of Dermatitis Associated with Dirofilaria repens in Pets: A Review of 100 Canine and 31 Feline Cases (1990-2010) and a Report of a New Clinic Case Imported from Italy to Dubai. J Parasitol Res 2011, 2011:578385.

65. Mihalca AD, Cazan CD, Sulesco T, Dumitrache MO: A historical review on vector distribution and epidemiology of human and animal leishmanioses in Eastern Europe. Res Vet Sci 2019, 123:185-191.

66. de Vasconcelos TCB, Furtado MC, Belo VS, Morgado FN, Figueiredo FB: Canine susceptibility to visceral leishmaniasis: A systematic review upon genetic aspects, considering breed factors and immunological concepts. Infect Genet Evol 2019, 74:103293.

67. Solano-Gallego L, Miró G, Koutinas A, Cardoso L, Pennisi MG, Ferrer L, Bourdeau P, Oliva G, Baneth G: LeishVet guidelines for the practical management of canine leishmaniosis. Parasit Vectors 2011, 4:86.

68. Dujardin JC, Campino L, Cañavate C, Dedet JP, Gradoni L, Soteriadou K, Mazeris A, Ozbel Y, Boelaert M: Spread of vector-borne diseases and neglect of Leishmaniasis, Europe. Emerg Infect Dis 2008, 14:1013-1018.

69. Leschnik M, Löwenstein M, Edelhofer R, Kirtz G: Imported non-endemic, arthropodborne and parasitic infectious diseases in Austrian dogs. Wien Klin Wochenschr 2008, 120(Suppl 4):59-62.

70. Willi B, Spiri AM, Meli ML, Grimm F, Beatrice L, Riond B, Bley T, Jordi R, Dennler M, Hofmann-Lehmann R: Clinical and molecular investigation of a canine distemper 
outbreak and vector-borne infections in a group of rescue dogs imported from Hungary to Switzerland. BMC Vet Res 2015, 11:154.

71. Maroli M, Feliciangeli MD, Bichaud L, CHarrel RN, Gradoni L: Phlebotomine sandflies and the spreading of leishmaniasis and other diseases of public health concern. Med Vet Entomol 2013, 27:123-147.

72. Obwaller AG, Karakus M, Poeppl W, Töz S, Özbel Y, Aspöck H, Walochnik J: Could Phlebotomus mascittii play a role as a natural vector for Leishmania infantum? New data. Parasit Vectors 2016, 19:458.

73. Vaselek S, Ayhan N, Oguz G, Erisoz Kasap O, Savić S, Di Muccio T, Gradoni L, Ozbel Y, Alten B, Petrić D: Sand fly and Leishmania spp. survey in Vojvodina (Serbia): first detection of Leishmania infantum DNA in sand flies and the first record of Phlebotomus (Transphlebotomus) mascittii Grassi, 1908. Parasit Vectors 2017, 10:444.

74. Colella V, Hodžić A, Iatta R, Baneth G, Alić A, Otranto D: Zoonotic Leishmaniasis, Bosnia and Herzegovina. Emerg Infect Dis 2019, 25:385-386.

75. Tánczos B, Balogh N, Király L, Biksi I, Szeredi L, Gyurkovsky M, Scalone A, Fiorentino E, Gramiccia M, Farkas R: First record of autochthonous canine leishmaniasis in Hungary. Vector Borne Zoonotic Dis 2012, 12:588-594.

76. Tsachev I, Kyriazis ID, Boutsini S, Karagouni E, Dotsika E: First report of canine visceral leishmaniasis in Bulgaria. Turkish J. Vet. Anim. Sci 2010, 34:465-469.

77. Dumitrache MO, Nachum-Biala Y, Gilad M, Mircean V, Cazan CD, Mihalca AD, Baneth G: The quest for canine leishmaniasis in Romania: the presence of an autochthonous focus with subclinical infections in an area where disease occurred. Parasit Vectors 2016, 9:297.

78. Maroli M, Rossi L, Baldelli R, Capelli G, Ferroglio E, Genchi C, Gramiccia M, Mortarino M, Pietrobelli M, Gradoni L: The northward spread of leishmaniasis in Italy: evidence from retrospective and ongoing studies on the canine reservoir and phlebotomine vectors. Trop Med Int Health 2008, 13:256-264.

79. Vaselek S, Dvorak V, Hlavackova K, Ayhan N, Halada P, Oguz G, Ivović V, Ozbel Y, Charrel RN, Alten B, Petrić D: A survey of sand flies (Diptera, Phlebotominae) along recurrent transit routes in Serbia. Acta Trop 2019, 197:105063.

80. Bosnić S, Gradoni L, Khoury C, Maroli M: A review of leishmaniasis in Dalmatia (Croatia) and results from recent surveys on phlebotomine sandflies in three southern counties. Acta Trop 2006, 99:42-49.

81. Lazri T, Duscher G, Edelhofer R, Bytyci B, Gjino P, Joachim A: Arthropod-borne parasites of dogs, especially Leishmania, in the Kosovo and Albania. Wien Klin Wochenschr 2008, 120(Suppl 4):54-58.

82. Karkamo V, Kaistinen A, Näreaho A, Dillard K, Vainio-Siukola K, Vidgrén G, Tuoresmäki $\mathrm{N}$, Anttila M: The first report of autochthonous non-vector-borne transmission of canine leishmaniosis in the Nordic countries. Acta Vet Scand 2014, 56:84.

83. Naucke TJ, Lorentz S: First report of venereal and vertical transmission of canine leishmaniosis from naturally infected dogs in Germany. Parasit Vectors 2012, 5:67.

84. Spada E, Canzi I, Baggiani L, Perego R, Vitale F, Migliazzo A, Proverbio D. 2016. Prevalence of Leishmania infantum and co-infections in stray cats in northern Italy. Comp Immunol Microbiol Infect Dis 2016, 45:53-58.

85. Pennisi MG, Cardoso L, Baneth G, Bourdeau P, Koutinas A, Miró G, Oliva G, SolanoGallego L: LeishVet update and recommendations on feline leishmaniosis. Parasit Vectors 2015, 8:302. 
86. Pennisi MG, Persichetti MF: Feline leishmaniosis: Is the cat a small dog? Vet Parasitol 2018, 251:131-137.

87. Pereira M, Valério-Bolas A, Santos-Mateus D, Alexandre-Pires G, Santos M, Rodrigues A, Rocha H, Santos A, Martins C, Tomas A, Passero F, da Fonseca IP, Santos-Gomes G: Canine neutrophils activate effector mechanisms in response to Leishmania infantum. Vet Parasitol 2017, 248:10-20.

88. Chitimia-Dobler L, Lemhöfer G, Król N, Bestehorn M, Dobler G, Pfeffer M: Repeated isolation of tick-borne encephalitis virus from adult Dermacentor reticulatus ticks in an endemic area in Germany. Parasit Vectors 2019, 12:90.

89. Leschnik MW, Kirtz GC, Thalhammer JG: Tick-borne encephalitis (TBE) in dogs. Int J Med Microbiol 2002, 291(Suppl33-):66-69.

90. Leschnik MW, Benetka V, Url A, Pakozdy A, Thaller D, Bilek A, Skerlak R, Möstl K: Viral encephalitis in dogs in Austria: diagnostic and epidemiological aspects. Wien Tierarztl Monatsschr 2008, 95:190-199.

91. Duscher GG, Leschnik M, Fuehrer HP, Joachim A: Wildlife reservoirs for vector-borne canine, feline and zoonotic infections in Austria. Int J Parasitol Parasites Wildl 2014, 4:8896.

92. Daniel M, Danielová V, Křriž B, Růžek D, Fialová A, Malý M, Materna J, Pejčoch M, Erhart $\mathrm{J}$ : The occurrence of Ixodes ricinus ticks and important tick-borne pathogens in areas with high tick-borne encephalitis prevalence in different altitudinal levels of the Czech Republic Part I. Ixodes ricinus ticks and tick-borne encephalitis virus. Epidemiol Mikrobiol Imunol 2016, 65:118-128.

93. Levanov L, Vera CP, Vapalahti O: Prevalence estimation of tick-borne encephalitis virus (TBEV) antibodies in dogs from Finland using novel dog anti-TBEV IgG MAb-capture and IgG immunofluorescence assays based on recombinant TBEV subviral particles. Ticks Tick Borne Dis 2016, 7:979-982.

94. Lukan M, Bullova E, Petko B: Climate warming and tick-borne encephalitis, Slovakia. Emerg Infect Dis 2010, 16:524-526.

95. Stadtbäumer K, Leschnik MW, Nell B: Tick-borne encephalitis virus as a possible cause of optic neuritis in a dog. Vet Ophthalmol 2004, 7:271-277.

96. Furness RW, Furness EN: Ixodes ricinus parasitism of birds increases at higher winter temperatures. J Vector Ecol 2018 43:59-62.

97. Klimeš J, Juřicová Z, Literák I, Schánilec P, Trachta e Silva E: Prevalence of antibodies to tick-borne encephalitis and West Nile flaviviruses and the clinical signs of tick-borne encephalitis in dogs in the Czech Republic. Vet Record 2001, 148:17-20.

98. Kirtz G, Leschnik M, Leidinger E: Ixodes ricinus: Dangerous for dogs! Kleintierpraxis 2001, 46:151-160.

99. Reiner B, Grasmück S, Steffen F, Djuric N, Schindler T, Müller W, Fischer A: Prevalence of TBE in serum and CSF of dogs with inflammatory and non-inflammatory CNS disease. Int J Med Microbiol 2002, 291(Suppl33):234.

100.Csángó PA, Blakstad E, Kirtz GC, Pedersen JE, Czettel B: Tick-borne encephalitis in southern Norway. Emerg Infect Dis 2004, 10:533-534.

101. Potkonjak A, Petrović T, Ristanović E, Lalić I, Vračar V, Savić S, Turkulov V, Čanak G, Milošević V, Vidanović D, Jurišić A, Petrović A, Petrović V: Molecular Detection and Serological Evidence of Tick-Borne Encephalitis Virus in Serbia. Vector Borne Zoonotic Dis 2017, 17:813-820. 
102.Bajer A, Rodo A, Bednarska M, Mierzejewska E, Welc-Falęciak R: Babesia canis and tickborne encephalitis virus (TBEV) co-infection in a sled dog. Ann Agric Environ Med 2013, 20:426-430.

103. Weissenböck H, Suchy A, Holzmann H: Tick-borne encephalitis in dogs: neuropathological findings and distribution of antigen. Acta Neuropathol 1998, 95:361-366.

104.Beckmann K, Steffen F, Ohlerth S, Kircher PR, Carrera I: Three tesla magnetic resonance imaging findings in 12 cases of canine central European tick-borne meningoencephalomyelitis. Vet Radiol Ultrasound 2016, 57:41-48.

\section{FOKUS NA VEKTORSKE BOLESTI MALIH ŽIVOTINJA U CENTRALNOJ I JUGOISTOČNOJ EVROPI}

\section{LESCHNIK Michael}

Vektorske bolesti su jedan od najčešćih uzroka morbiditeta i mortaliteta malih životinja u Evropi. Mnoge od ovih bolesti su dobro poznate veterinarima koji se bave praksom, a neke od njih se obzirom na porast njihove prevalencije, prostorne i vremenske distribucije u Evropi nazivaju „emerdžing“ bolestima. Broj novoprepoznatih patogena čiji su prenosioci tj. vektori artropode je iz godine u godinu u porastu. Prevalenca među inficiranim vektorima i domaćinima predstavlja značajnu temu u veterinarskoj nauci širom kontinenta, kao i razvoj efikasnih dijagnostičkih procedura, terapija i profilaktičkih mera. Vektorske bolesti kućnih ljubimaca obuhvataju veliku grupu patogena, uključujući viruse, bakterije, protozoe i helminte. Ove patogene mahom prenose artropode koje sisaju krv (krpelji, buve, komarci i peščane mušice), a znatno ređe direktnom transmisijom između kičmenjaka tj.domaćina. Prevalenca i aktivnost vektora zavisi od klimatskih uslova, gustine naseljenosti domaćina, promena u životnom okruženju i uoptrebe zemljišta. Humani parametri, kao što su siromaštvo i migracije utiču na primenu profilaktičkih mera protiv prenosa patogena i infekcije, uz istovremno povećanje rizika od zoonoze koje nastaju kao posledica uvođenja patogena preko inficiranih ljudi. Faktori koji se odnose na male životinje, kao što je slučaj sa trgovinom i putovanjima ljubimaca, šire infekciju i vektore kao što su krpelji i buve. Svi ovi faktori predstavljaju značajne i složene izazove za veterinare u kliničkoj praksi koji moraju da se opredele za efikasne laboratorijske pretrage i posledične dijagnostičke procedure. 